\title{
Analysis of Law Discourse Through Van Dijk Model Approach
}

\author{
${\text { Muhammad Syukri }{ }^{*}, \text { Muh. Azhar Nur }{ }^{2} \text {, Karina Alifiana Karunia }}^{2}$ \\ ${ }^{I}$ Tarbiyah and Teacher Training, Institute of Islamic Muhammadiyah Sinjai, Indonesia \\ ${ }^{2}$ Economic and Islamic Law, Institute of Islamic Muhammadiyah Sinjai, Indonesia \\ *Corresponding author. Email: syukri.burhan@gmail.com
}

\begin{abstract}
This paper present analysis of law discourse relates to the study of language or language usage. The analysis approach that is used in this research is a critical model of discourse analysis as known as Critical Discourse Analysis (CDA) is seen in the use of speech and writing as social practice. The data collected by using a library research from manuscript related to law, and analysis model uses Van Dijk approach for analysis. The results of the research indicate that the use of certain words, sentences, certain styles is not merely seen as a way of communicating, but is seen as communicating the politics a way to influence public opinion, create support, strengthen legitimacy, and remove opponents or opponents. The significance of this research is how the reader not only get information from a law discourse but also get meaning what the writer tries to convey through the text from an analysis by using critical discourse approach.
\end{abstract}

Keywords: discourse analysis, critical discourse, text, meaning, information

\section{INTRODUCTION}

Discourse can be seen from the form of power relations, especially in the formation of subjects and various acts of representation. Such disclosure is intended in this case to be a critical discourse analysis (CDA). The basic understanding of CDA is that discourse is not understood solely as an object of language study. Language is of course used to analyze text.

The term discourse analysis is a generic term used in many disciplines and in various senses. Qin Sie stated that news discourse is one of main analysis subjects of critical discourse analysis. People can know the opinions implied by the author and grasp the real situation of the events described in the discourse by critical discourse analysis. Furthermore, it is beneficial for the audience to establish the critical awareness of News discourse and enhance the ability to critically analyze news discourse. Based on the discussion of the concept of news discourse and critical discourse analysis, the theoretical foundations and steps of critical discourse analysis, the paper illustrates the method of the critical analysis of news discourse. The author also puts forward issues that needed to pay attention to in order to improve the ability of news discourse analysis [1].

Related to the statement above, Gee and Handford pointed out that sometimes the term "pragmatics" is use for the study of language in use. It is the study of the meaning we give language and the action the carry out when we use language in specific contexts. Discourse analysis is also sometimes defined as the study of language above the level of a sentences, of the ways sentences combine to create meaning, coherence, and accomplish purposes [2].

The statement above is supported by Tannen stated that "Discourse analysis: Text and Talk and invited as speaker linguists, anthropolinguist, psycholinguists, all of whom examining language in contexts. It means that, when we come to analysis a text or discourse, at that time there are many aspects including in the analysis process [3].

In this case, the aspects that can present in a text or communicative discourse is background of the writer culture. Paulston, et.al. stated that culture may have been in contact since time immemorial but the means of sharing such experience long distance and over time did not exist as it does today. It does not need much reflection to realize that such sharing as did then exist was based on feature which struck the writer as noticeable and unusual [4]. Critical Discourse Analysis (Critical Discourse Analysis) The critical discourse analysis (CDA) is an attempt or process to describe a text (social reality) that is willing or being studied by a dominant person or group whose tendency has a particular purpose to obtain what is desired. That is, in a context must be aware of the existence of interest. Therefore, then analyzes that are formed will later be influenced by the author of various factors. In addition, it must be realized also that behind the discourse there is a meaning and the desired image and interests that are being fought.

A. Van Dijk argues that "CDA is used to analyze critical discourses, including politics, race, gender, social class, hegemony, etc.". Furthermore, Fairclough and Wodak summarize the principles of the teaching of the CDA as follows: (1). Discuss social issues, (2). Revealing that the relation of power relation is discursive, (3). Uncover culture and society, (4). Ideological, (5). Historical, (6). Suggests the relationship between text and society, (7). Be interpretative and explanatory.

Van Dijk sees a text consisting of several structures / levels in which each part is mutually supportive. He divides it into 3 levels. First, macro structure. This is a global / general meaning of a text that can be observed by looking at the topic or theme put forward in a story. Second, the superstructure. This is a discourse structure that relates to 
the textual framework of the text, how the parts of the text are composed into the news intact. Third, the micro structure. Is the meaning of discourse that can be observed from a small part of a text word, sentence, proposition, clause, paraphrase, and image. If described then the structure of the text is as follows:

Table 1. Scheme of Discourse

\begin{tabular}{l} 
Macro Structure \\
The global significance of an observable text \\
From the topic/ theme raised by a text \\
\hline Superstructure \\
The framework of a text, such as the introduction, \\
Contents, conclusions, and conclusions \\
Micro Structure \\
The local meaning of a text can be observed \\
From the choice of words, sentences and styles used by a text
\end{tabular}

The use of certain words, sentences, propositions, rhetoric of the media understands van Dijk as part of a journalist's strategy. The use of certain words, sentences, certain styles is not merely seen as a way of communicating, but is seen as communicating politics-a way to influence public opinion, create support, strengthen legitimacy, and remove opponents or opponents. Discourse structures are an effective way of looking at the process of rhetoric and persuasion that is executed when a person conveys a message.

Table 2 Elements of Discourse

\begin{tabular}{|c|c|c|}
\hline $\begin{array}{l}\text { Discourse } \\
\text { Structure }\end{array}$ & Aspects Are Looked & Elements \\
\hline Macro Strucutre & $\begin{array}{l}\text { Thematic } \\
\text { Themes / Topics put forward in a story }\end{array}$ & Topic \\
\hline Superstructure & $\begin{array}{l}\text { Schematic } \\
\text { How parts and sequences of news are } \\
\text { shrunk in the full text }\end{array}$ & Scheme \\
\hline Micro Structure & $\begin{array}{l}\text { Semantics } \\
\text { The meaning to be emphasized in the text } \\
\text { of the news, eg with the details on one side } \\
\text { or make explicit one side and reduce the } \\
\text { details of the other side. } \\
\text { Syntax } \\
\text { How the sentence (shape, arrangement) is } \\
\text { selected.Stilistik } \\
\text { How to choose the word used in the news } \\
\text { text. } \\
\text { Rhetorical } \\
\text { How and by means of emphasis is done. }\end{array}$ & $\begin{array}{l}\text { Background, } \\
\text { details, intent, } \\
\text { pre-assumption, } \\
\text { nominalization } \\
\text { Sentence form. } \\
\text { Coherence, } \\
\text { Pronoun. } \\
\\
\text { Lexicon } \\
\text { Graphics, } \\
\text { Metaphors, } \\
\text { Expressions. }\end{array}$ \\
\hline
\end{tabular}

In van Dijk's view, all texts can be analyzed using those elements. Although it consists of various elements, all these elements are a unity, interconnected and supportive of each other. Discourse by van Dijk is described as having three dimensions: text, social cognition, and social context. Dijk combines the three dimensions of the discourse into an integrated analysis. In the text, what is examined is how the structure of the text and discourse strategies is used to affirm a particular theme. Social cognition studies the process of news text induction involving individual cognition from journalists [5]. Furthermore, Rahimi argued that CDA propagates the idea that enhancement of critical thinking is conducive to a society in which justice and equality are materialized and power is distributed fairly among people.
This mental ability makes readers and listeners perceptive to judgmental prejudiced discourse and prompts them to act against injustice and incommensurate distribution of power [6]. Based on the topic above, the objective of this research is to find out the aspect of critical discourse analysis in a law discourse. Some aspects that will be focused on of the text are macro structure, superstructure, and micro structure. Theoretically, this study illustrates the importance of a linguistic approach in understanding the content of discourse, especially law discourses that fill public literacy particularly in Indonesia.

\section{METHOD}

Discourse analysis is a discipline that seeks to examine the use of real language in communication. Stubbs says that discourse analysis is a study that examines and analyzes the language used naturally, both oral and written, for example the use of language in everyday communication [7]. In this research, to collecting the data is usable library research where a lower discourse Submitted by creeper on Mon, 2011-09-12 11:48 and analysis by using Van Dijk approach in some aspects. The aspects those used to analysis of discourse structure in two parts are macro and micro structure.

\section{RESULTS AND DISCUSSION}

\subsection{Thematic}

This theme is very interesting if brought on the provision of information to the public about the implementation and application of law norms injustice, in order to realize the five principles of Pancasila namely social justice for all Indonesian people. In addition to linguistics, this type of discourse is interesting to analyze to see how this structure of discourse is formed and how the use of the vocabulary reflects this type of discourse.

Phantasmagoria law enforcement in Indonesia means that law enforcement in this country is full of falsehood and mere rhetoric so that it is getting away from creating a real law enforcement. As we can see in the sentence:

"The stage of law enforcement is like a phantasmagoria performance, a world displaying the appearance of imaginary beings and the removal of the ultimate beings caused and controlled by the powerful passion enveloping the law-enforcement stage itself."

Thus, the simple picture of the frenzied execution of laws that seem to be selective and not in favor of the interests of the State, the people, but rather the interests of power, which in the end will only lead to the misery of the people as we can see in the sentence:

"Unfortunately, continued Foucault, the interests combine the power of political power, the carrying capacity of capital and imaging of the media so that transforms the form of knowledge, truth and justice into something very complex and no longer sterile scientifically from outside the elements. Now, that truth becomes a three-dimensional standard; power, capital and the media. Thus, law justice 
or law truth becomes very vague because it has been dominated by new images that are the turning point of truth and justice of the law itself".

From that perspective, it is clear that law enforcement is arbitrary, as long as power and political interests envelop the whole commandment in the land so long as the law is just a mirage that exists only in dreams.

\subsection{Schematic}

Based on the composition of this law discourse, it is packaged starting from the introduction, the contents of the problem, and its solving, and until the end (cover) story. In the preliminary section described what is phantasmagoria law enforcement? then the problem that arises is the existence of a gap between the essential reality with the reality of images that are displayed and presented to the public.

The technique of delivering authors in this paper is quite communicative, although the language styles are a bit metaphorical. The form of a direct relationship can be felt because the word forms are sufficiently understood and familiar to the reader so that between the author and the reader aligned. In addition, it also brings about the atmosphere evocative of the reader's emotions.

The sequence of submission of this law discourse can be seen as follows:

a. The new ROUND of law enforcement in the case of M Nazaruddin, former Treasurer of the Democratic Party continues to roll.

b. Although law proceedings continue, public space is more dominated by dimensions that do not come into contact with the law.

c. Both new phenomena that emerged lately can be a counter fact of the real case of corruption Nazaruddin. The flow of public observation, then shifted from law cases to humanitarian stories about the kinship and drama of salvation

d. Strengthening the judicial system is done by maximizing the control function of the products or judicial decisions

e. The importance of control, power, in order to safeguard objectivity of judicial decisions from external elemental interventions to law enforcement officers.

f. Indeed, law enforcement officers are individuals who are truly morally independent and have integrity that can be accounted for. Thus, the reform of law enforcement officers should not follow the logic of the State Employer conventionally, both in terms of rank and honorarium. But it should be aimed at strengthening the moral base and sharpening of the vision of law enforcement that is supported by sufficient welfare, so that in the future they really become a solid bastion of law enforcement in Indonesia.

\subsection{Semantic}

Background, details, intent (explicit/ implicit), presupposition. a. Conceptual Meaning

The conceptual meaning that can be drawn from this Law Discourse is as follows:

1) law (paragraph 1) rules, norms

2) the world (paragraph 1) earth foothold

3) Nazaruddin (paragraph 2) the name of a person

4) suspect (paragraph 2) of the defendant

5) country (paragraph 2) homeland, country

6) asylum (paragraph 3) protection

7) public (paragraph 4) of society

8) power (paragraph 5) power, power

9) scientists (paragraph 6) who are experts in science

10) action (paragraph 7) action, action

11) fight (paragraph 8) resistance, conflict

12) own (paragraph 9) self

13) distance (paragraph 10) span of place and time

14) false (paragraph 11) a lie, a lie

15) eyes (paragraph 12) sense of sight

16) judge (paragraph 13) of the judge

17) moral (paragraph 14) morals

b. Connotative Meaning

The connotative meaning of the phrase "The new ROUND law enforcement case of $M$ Nazaruddin, former Treasurer of the Democratic Party continues to roll". That the corruption case that be felled $\mathrm{M}$. Nazaruddin continues the law process, and become the public spotlight.

c. Social Meaning

The social meaning of the Discourse with the topic "Phantasmagoria" of law enforcement in Indonesia is that it is directly related to other cultural, economic, political and social values as in the following phrase:

"As a battleground, Foucault says, the law enforcement discourse in it is overwhelmed by wars (interests, languages, races, conflicts) that provide opportunities and opportunities and risks and rubs against new interests such as politics, economics, position and other social interests.

d. Affective Meaning

Affective meanings related to this discourse are:

"Indeed, law enforcement officers are individuals who are truly morally independent and have integrity that can be accounted for. Thus, the reform of law enforcement officers should not follow the logic of the Civil Servant (PNS) conventionally, both in terms of rank and honorarium. But it should be aimed at strengthening the moral base and sharpening of the vision of law enforcement that is supported by sufficient welfare, so that in the future they really become a solid bastion of law enforcement in Indonesia"

e. Reflective Meaning

The reflective meaning of this Law Discourse is, for example the word judge associated with justice and the political word associated with power.

f. Connotative Meaning

If words such as suspects, corruption, judges, guarantees, enforcement, appeals, asylum, so the lexicons, all referring to and relating to law or judicial matters, while if we use words of justice, truth, the hope of creating the desired state of an enforced law process. Furthermore, if the words of academics, civil servants $(P N S)$, or the social resources of association (LSM) then 
the meaning with regard to the position, profession or a particular institution. Meanwhile, if we call Wisma Atlit Palembang, then the name was related to a building in South Sumatra.

g. Thematic Meaning

Thematic meanings are the meanings that are communicated in a way in which the message is arranged on the basis of a pressure sequence or in other words.

"It is Michel Foucault, a French scientist who has conducted massive research on discourse, especially law as a discourse. This French scientist discovered the fact that every law discourse cannot be separated from the operation of certain powers (power) and knowledge (knowledge) and social relations between the two that result in law decisions and then known with justice and truth.

The sequence of events can be broken down into:

1) Is Michel Foucault (1997), a French scientist has done a massive research about discourse, especially the law as a discourse Assisted by the ship's sailor.

2) The French scientist found a fact that every law discourse cannot be separated from the operation of certain powers (power) and knowledge (knowledge) and social relations

3) Justice and truth [8]

The background of this incident is in Palembang, in the form of a case about the construction of Palembang Athletic Houses which will be used for SEA GAMES 2011 activities that cost the State about 6.4 Trillion rupiah.

Next time background as in using only one-time indicator word "temporary". The background time in detail, we can see:

Table 3 Thematic Meaning

\begin{tabular}{|c|c|}
\hline Background & Citation \\
\hline $\begin{array}{l}\text { New } \\
\text { Round }\end{array}$ & $\begin{array}{l}\text { "the New Round" of the law enforcement case M } \\
\text { Nazaruddin, former Treasurer of the Democratic } \\
\text { Party continues rolling" }\end{array}$ \\
\hline Continues & $\begin{array}{l}\text { "Although the law process continues, but public } \\
\text { news spaces are more dominated by dimensions that } \\
\text { are not in contact with the law" }\end{array}$ \\
\hline While & $\begin{array}{l}\text { "Meanwhile, revamping the law enforcement } \\
\text { officers into something very important because in } \\
\text { their hands the color and pattern of law } \\
\text { enforcement" }\end{array}$ \\
\hline Forward & $\begin{array}{l}\text { "So that in the future they really become a solid } \\
\text { bastion of law enforcement in Indonesia" }\end{array}$ \\
\hline
\end{tabular}

Detailed events can be raised if referring to the above law discourse is:

The description of "phantasmogaria" by the author in use at the beginning of this text, implies that law enforcement in Indonesia is like a world displaying the appearance of imaginary beings and the abolition of the ultimate beings caused and driven by a power of passion so strongly enveloping the stage of law enforcement own.

While the social background can be seen in the fifth paragraph related to the above theme is in the example of quotation:

"As we all know, M Nazaruddin once wrote a letter to the President that contained an " asylum " plea for his family's fate with no guarantee of dismantling the facts of the
Democratic Party's involvement. In addition, Nazaruddin also requested the transfer of detention space from Mako Brimob to another detention room on the grounds of threatened safety assurance .. "

In addition, detailed elements can also be seen in the fourth paragraph related to the above:

"The two new phenomena that have emerged in recent years can be counter facts of the real case of Nazaruddin corruption".

In paragraph (14) "Indeed, law enforcement officers are individuals who are truly morally independent and have integrity that can be justified.... etc. put forward one solution in order to get out of the stingy issues about the achievement of justice and truth in law enforcement in Indonesia "... .etc.

\subsection{Syntax}

a. Cohesion

Grammatical cohesion includes pronominal, substitution, and conjunction. While lexical cohesion includes equivalence, repetition, antonym, synonym, hyponym, and collocation. Grammatical Cohesion; is using some cohesive means in it like pronouns (pronominal). In referring to the analysis above, Fairclough stated that discourse analysis which aims to systematically explore often opaque relationship of causality and determination between (a) discursive practice, events and texts, (b) wider social and cultural structures, relation and processes; to investigate how such practices, events and texts arise out of and are ideologically shaped by relations of power and struggle over power [9].

Grammatical cohesion also includes substitution of the process or result of substitution of elements of language by other elements in larger units to obtain the differentiating elements or to explain a particular structure. As follows:

Table 4 Grammatical Cohesion

\begin{tabular}{|lll|}
\hline Substitution & Citation & Paragraph \\
\hline is & $\begin{array}{l}\text { Is Michel Foucault, a French scientist Paragraph 6 } \\
\text { has been doing massive research on (1 time) } \\
\text { discourse, especially the law as a } \\
\text { discourse }\end{array}$ \\
\hline Unfortunately & $\begin{array}{l}\text { Unfortunately, continued Foucault, Paragraph 9 } \\
\text { the interests that blend between the (1 time) } \\
\text { power of political power, the carrying } \\
\text { capacity......etc. }\end{array}$ \\
\hline the & $\begin{array}{l}\text { The problem is, there is always a Paragraph1 } \\
\text { problem } \\
\text { reality with the reality of images } \\
\text { displayed and served ... etc. }\end{array}$ \\
\hline Thus & $\begin{array}{l}\text { Thus, to disclose the truth and law Paragraph } \\
\text { justice, it takes a partisanship to 12 (1 time) } \\
\text { values...... }\end{array}$ \\
\hline Therefore & $\begin{array}{l}\text { Thus, law justice or law truth becomes Paragraph 9 } \\
\text { very clear because it has been (1 time) } \\
\text { dominated by new images that are the } \\
\text { turning point of truth and justice of the } \\
\text { law itself. }\end{array}$ \\
\hline
\end{tabular}

b. Coherence

According to $\mathrm{C}$. Wallace, coherence is grammatical and semantic interconnectedness between sentences that 
form a text. It is the semantic structure, not its formal meaning, which create coherence. Coherency is a condition where sentences in a text hang together. It can occur in relation of sentences that immediately follow each other [10].

c. Addition or addition, namely usage with, also the following:

"M Nazaruddin once wrote a letter to the President which contained an application. "Asylum " for the fate of his family with a guarantee will not uncover the facts of the Democratic Party's involvement. In addition, Nazaruddin also requested the transfer of the detention room from the Brimob Mako to another detention room on the grounds of guaranteed safety...

Series or series of events with the word after that, then for example:

"Continued by Foucault, that interest was combined between the power of political power, the carrying capacity of capital and the image of the media so that it transformed the form of knowledge, truth and justice into something that was very complex and no longer scientifically sterile from external elements."

"Now, the truth is a three-dimensional standard; power, capital and the media. Thus, law justice or the truth of the law becomes very marginal because it has been controlled by new images which are the turning point of the truth and law justice itself.

d. Repetition or repetition is the repetition of lingual units such as sounds, syllables, words or parts of sentences. For example:

1) Epizeuksis is successive repetition. For example:

"In the world of simulacra, a law enforcement process and mechanism does not work; there were investigations and investigations, the trial process also continued witnesses and defendants were also present. There is nothing less procedurally. But all are pseudo (false) and false (lies), for example the defendant pretends to be sick, pretends to forget or deliberately forgets".

2) Tautotes is several times in a construction for example:

"The law enforcement stage is like staging phantasmagoria, a world that displays the appearance of imaginary forms and the elimination of essential forms that are caused and controlled by the desire of power that is so strong that covers the stage of law enforcement itself. This phantasmagoria displays inverse forms that allow the bending of reality to the artificial dimensions. "

Anaphora, repetition as a word, the first phrase in each row. For example:

"Here progressively becomes very important to unravel the complexity of the combination of power, capital and media that is haunting the justice system and our law enforcement system. The progressives start from strengthening the judicial system which is based on two things, namely strong control, and the improvement of personnel of the law enforcement agencies so that the law can run objectively and fairly."

Other elements that can require discourse on this Law Discourse includes:
Emphasis is a means that can add to the complexity of discourse, for example:

"Indeed, law enforcement officers are individuals who are truly morally independent and have integrity that can accounted for. Thus, reform of law enforcement officer should not follow the logic of the "Civil Servant" in conventional terms, both in terms of rank and honorarium. But it must be directed at strengthening the moral basis and sharpening the vision of law enforcement that is supported by sufficient welfare, $\boldsymbol{S o}$ that in the future they will truly become a strong fortress of law enforcement in Indonesia. In this case, related to this aspect Yoce stated that in interpreting text, there are four domains of interpretation namely (1) speech form (speech meaning), (3) local coherence, and (3) text structure ), while there are two domains in interpreting context, namely situational context and intertextual context [11].

\subsection{Stilistics}

Is the choice of words that used can be seen based on the text as follows?

Question words, Noun, Verbs, Adjectives,Number words Contact, Owned, Word ahead, Pronoun, Clothing, and Adverb

\subsection{Rhetoric}

Is includes forms in the form of expansions, structural structuring, and imaging:

a. Exposure in the form of:

1) Hyperbole language style for example:

"The flow of public observation, then shifted from a law case to human stories about family and drama of salvation."

2) Metaphor for example:

"The law enforcement stage is like a phantasmagoria staging,

b. Weeding Structure for example: repetition, climax and others. For example:

"As a battleground, said Foucault, the law enforcement discourse in it is filled with war (interests, language, race, conflict) that provide opportunities and opportunities and risks and rub against new interests such as politics, economy, position and other social interests. So, negotiations will fight against efforts to stabilize the power and perpetuate interests that surround it. These interests present imaginary realities to deviate objective reality so as to present the facts of the new law discourse which is completely different.

c. Imaging is: imaging of vision, hearing, or movement. Vision imagery, for example:

"What reads this case? Although the law process continues, the public reporting space is more dominated by dimensions that are not in contact with the law."

The flow of public observation then shifts from a law case to human stories about family and drama of salvation. 


\section{ACKNOWLEDGMENT}

"In addition, Nazaruddin also requested the transfer of detention rooms from the Mako Brimob to other detention rooms on the grounds of the threatened safety guarantee".

\subsection{Vocabulary Used}

The word reset is the basic word or basic form that experiences repetition, both whole and in part while compound words are a combination of several different basic words forming a new meaning.

In the standard Indonesian grammar, the word class is divided into seven categories, namely:

a. Noun (noun); the name of a person, place, or all objects and everything that is dammed, such as books, horses. Example of text:

Nazaruddin, Palembang Athlete House, Mako Brimob, Detention room, Democratic party, Corruption Eradication Commission

b. Verbs (verbs); words that express a dynamic action or understanding, for example reading, running.

1) Transitive verbs writing a letter, show, give, express, frame

2) Intransitive work verbs controlled, threatened, truth, justice, haunt

3) Complementary

solved, personnel, PNS (Civil Servant), LSM (nongovernmental organization academy)

c. Adjective (adjective); words that describe nouns, for example hard, fast. Examples of texts are: strong, sturdy, fair etc.

d. Adverb (adverb); words that give information to words that are not nouns, for example now, temporary etc.

e. Pronomina (pronoun); substitute words for nouns, for example, he, us, them

f. Numerals (number words); a word that states the number of objects or things or shows the order in a row, for example one, second.

1) Cardinal number (six point 4 )

2) Ordinal number (both)

g. The task word is a type of word outside the words above which based on its role can be divided into five subgroups:

1) Prepositions (prepositions) (example: in, to, on)

2) Conjunctions (conjunctions) - Conjunctions coordinate (and), subordinate conjunctions (because, but, but),

3) Articula (article) (example: sang)

4) Particles. (is Michel Foucoult).

\section{CONCLUSION}

Critical analysis discourse on law discourse something new with Van Dijk. T theoretical approach. Aspects that can be developed are reviews of the structure of discourse, namely Micro, Macro and superstructure. The discourse analysis approach with the Van Dijk model contributes to the development of discourse analysis regarding the linguistic aspects of discourse as well as law discourse.
I would like to express my deep appreciation and sincere thanks to all of them, particularly to Dr. Firdaus, M, Ag. The Rector, Institute of Islamic Religion of Muhammadiyah Sinjai who always support me to finishing this manuscript. And also Dr. Ismail, M.Pd. Vice of Rector IAIM Sinjai who giving cost supporting and I would like to say thanks to all for supporting this research. He hopes it will be considered as important things to give contribution in order to improve the CDA (Critical Discourse Analysis) particulars of the public information. Thank you.

\section{REFERENCES}

[1] Qin Sie, "Critical Discourse Analysis of news discourse," Theory Pract. Lang. Stud., vol. 8, no. 4, p. 399, 2018.

[2] M. H. J.Gee, The Routledge Handbook of Discourse Analysis [electronic resource]. 2011.

[3] H. H. D.Schiffrin, D.Tannen, the handbook of discourse analysis, no. 1-851. 2008.

[4] E. R. C. Paulston, S. Kiesling, The handbook of intercultural discourse and communication. 2012.

[5] Teun Van Dijk, Discourse as Social Interaction. 1988.

[6] F. M. J. R. Rahimi, "Critical Discourse Analysis: Scrutinizing Ideologically-Driven Discourses," Int. J. Humanit. Soc. Sci., vol. 1, no. 16, pp. 107-112, 2011.

[7] M. Stubbs, Discourse Analysis: The Sociolinguistic Analysis of Natural Language. 1983.

[8] Michael foucault, Seks dan Kekuasaan, translate by Rahayu s. 1997.

[9] R. Fairclough, N., \& Wodak, "Critical Discourse Analysis," A Multidiscip. Introd., vol. 2, no. Discourse studies, pp. 258-284, 1997.

[10] C. Wallace, "Critical Discourse Analysis and Critical Reading,” Crit. Read. Lang. Educ., pp. 26-48, 2003.

[11] Yoce Aliah Darma, Critical Discourse Analysisi. 2009. 